\title{
$1.0 \mathrm{eV} \mathrm{GaAs}$ 基 InAs 量子点太阳能电池
}

王文奇 1,2 , 王禄 $1^{1,2 *}$, 江洋 1,2 , 马紫光 ${ }^{1,2}$, 孙令 ${ }^{1,2}$, 刘洁 ${ }^{1,2}$, 王文新 ${ }^{1,2}$, 贾海强 1,2 , 陈弘 1,2

1. 中国科学院物理研究所, 北京凝聚态物理国家实验室, 北京 100190 ;

2. 中国科学院大学, 北京 100049

* 联系人, E-mail: lwang@iphy.ac.cn

2017-03-15 收稿, 2017-03-31 修回, 2017-03-31 接受, 2017-07-26 网络版发表

国家自然科学基金(11574362, 61210014, 11374340, 11474205)和北京市科技计划(Z151100003515001)资助

摘要 三结 $\mathrm{InGaP} / \mathrm{GaAs} / \mathrm{Ge}$ 太阳能电池理论设计中加入带隙为 $1.0 \mathrm{eV}$ 的材料代替带隙为 $1.4 \mathrm{eV}$ 的 $\mathrm{GaAs}$ 中间电池 有助于解决多结串联电池的电流阻塞效应实现电流匹配，然而带隙为 $1.0 \mathrm{eV}$ 的 InGaAs 和 GaInNAs外延困难。我们 利用分子束外延方法外延得到 $\mathrm{In}_{0.15} \mathrm{Ga}_{0.85} \mathrm{As}$ 量子阱, InAs dots-in-well量子点以调整太阳能电池带隙. X射线衍射谱 中观察到了量子阱的多级卫星衍射峰，量子阱界面陡峭. 扫描透射图显示量子点呈金字塔状，量子点的高度约为 $12 \mathrm{~nm}$, 底边长约为 $27 \mathrm{~nm}$. 由原子力显微镜图可知, 量子点密度约为 $2 \times 10^{10} \mathrm{~cm}^{-2}$. 低温光致发光谱显示量子点在 $\mathrm{As}_{4}$ 束流下呈双模分布. 光电流响应谱显示InAs dots-in-well量子点太阳能电池吸收波长可以达到 $1300 \mathrm{~nm}$, 相应于 带隙约为 $1.0 \mathrm{eV}$. 器件 $J-V$ 特性显示短路电流相比于 GaAs标准p-i-n电池增加了 $37.8 \%$. 这表明该InAs dots-in-well量 子点太阳能电池有望改善多结太阳能电池的设计中的电流阻塞效应, 实现电流匹配, 在多结太阳能电池的设计中 具有广阔的应用前景。

关键词量子点, III - $\mathrm{V}$ 半导体, 太阳能电池

近年来, GaAs基单节太阳能电池和多节太阳能 电池广泛应用于空间电池技术和制造聚光太阳能电 池 $^{[1 \sim 5]}$. 最常用的三结太阳能电池多采用 $\mathrm{Ge}$ 作为底电 池, GaAs为中间电池, InGaP为顶电池, 带隙分别为 $0.7,1.4,1.9 \mathrm{eV}^{[6,7]}$. 在三结太阳能电池中, $\mathrm{GaAs}$ 结电 池短路电流密度低于其他两结电池. 而三结电池的 短路电流取决于子电池短路电流的最小值, 因此, GaAs 结电池限制了三结太阳能电池转换效率的提 高 $^{[8]}$.

为了扩展GaAs太阳能电池的吸收波长, 国内外 学者提出在GaAs p-i-n电池的耗尽区加人量子阱结 构, 应力平衡, 有效地扩展了电池的吸收波长 ${ }^{[9]}$. 根 据理论计算, 在 $\mathrm{InGaP} / \mathrm{GaAs} / \mathrm{Ge}$ 多结电池中串联一 个带隙为 $1.0 \mathrm{eV}$ 的电池替代 $\mathrm{GaAs}$ 子电池会扩展光谱
吸收增大电池效率 ${ }^{[10]}$. 常用的带隙为 $1.0 \mathrm{eV}$ 的材料有 晶格匹配的 GaInNAs 和晶格失配的 $\mathrm{In}_{0.3} \mathrm{Ga}_{0.7} \mathrm{As}^{[11,12]}$. GaInNAs少子寿命短, 载流子迁移率低, 少子扩散长 度小于耗尽区宽度 ${ }^{[13,14]} ; \mathrm{In}_{0.3} \mathrm{Ga}_{0.7} \mathrm{As}$ 与 $\mathrm{Ge}$ 晶格失配 大, 大尺寸的异质外延很困难 ${ }^{[8]}$. 改善晶体外延质量 和设计新结构的太阳能电池是提高光电转换效率的 方法.

引人应力平衡的低维半导体结构, 如量子阱和 量子点结构, 不仅提高了异质外延的晶体质量, 而且 可以通过调节势阱带隙来调节电池的光谱吸收，进 而提高电池的光电转换效率 ${ }^{[15 ~ 18]}$. 多结太阳能电池 为串联结构, 其开路电压为各子电池开路电压之和. 因此, 尽管基于低维半导体材料的太阳能电池存在 降低的开路电压的缺陷, 但在多结电池串联应用中, 
并不影响多结电池的整体效率 ${ }^{[19]}$. 另外, 量子阱和 量子点太阳能电池显示出优越的抗辐照性能和较高 的温度系数，在空间技术方面具有应用潜力 ${ }^{[20 ~ 22]}$. 目前, 可以通过调整生长参数来获得光致发光峰在 $1300 \mathrm{~nm}$ 的InAs量子点材料, 该波长的材料主要应用 于激光器的制备, 关于将该种材料应用于太阳能电 池鲜有报道 ${ }^{[23,24]}$.

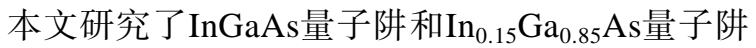
中InAs 量子点在 $1.0 \mathrm{eV}$ 电池中的适用性. 通过外延得 到包含该结构的 $\mathrm{GaAs}$ 基太阳能电池, 并测试其光伏 性能, 发现该结构的太阳能电池吸收波长扩展到 $1300 \mathrm{~nm}$, 接近带隙 $1.0 \mathrm{eV}$, 短路电流相比于 $\mathrm{GaAs}$ 电 池提高了 $36.7 \%$.

\section{1 实验}

本实验的 3 个样品通过分子束外延 $(\mathrm{V} 80 \mathrm{H})$ 方法,
在 $\mathrm{p}$ 型 $\mathrm{GaAs}(100)$ 衬底上外延生长制得. 样品结构如 图1所示, 样品 $\mathrm{A}$ 是一个标准的 GaAs单节pin结构太阳 能电池： $\mathrm{p}$ 区欧姆接触层厚度为 $300 \mathrm{~nm}$, 掺杂浓度为 $N_{\mathrm{A}}=3 \times 10^{18} \mathrm{~cm}^{-3}$, 基区厚度为 $300 \mathrm{~nm}, \mathrm{Be}$ 掺杂浓度为 $N_{\mathrm{A}}=5 \times 10^{17} \mathrm{~cm}^{-3}$, 本征区 $\mathrm{GaAs}$ 厚度为 $630 \mathrm{~nm}$, 发射区 厚度为 $150 \mathrm{~nm}, \mathrm{Si}$ 掺杂浓度为 $N_{\mathrm{D}}=5 \times 10^{17} \mathrm{~cm}^{-3}, \mathrm{n}$ 区 欧 姆接触层厚度为 $300 \mathrm{~nm}, N_{\mathrm{D}}=3 \times 10^{18} \mathrm{~cm}^{-3}$. 样品 $\mathrm{B}$ 和样 品 $\mathrm{C}$ 只是本征区结构与样品 $\mathrm{A}$ 不同, 电极结构相同, 厚度相同. 样品 $\mathrm{B}$ 的厚度为 $630 \mathrm{~nm}, 10$ 个 $8 \mathrm{~nm}$ 的 $\mathrm{In}_{0.15} \mathrm{Ga}_{0.85} \mathrm{As}$ 量子阱结构均匀地穿插在 11 个 $50 \mathrm{~nm}$ $\mathrm{GaAs}$ 隔离层中间, 而样品 $\mathrm{C}$ 中是在样品 $\mathrm{B}$ 中的 $\mathrm{In}_{0.15} \mathrm{Ga}_{0.85} \mathrm{As}$ 量子阱中插人 $2.2 \mathrm{ML}$ (monolayer)的InAs 量子点, 即在 $2 \mathrm{~nm}$ 的 $\mathrm{In}_{0.15} \mathrm{Ga}_{0.85} \mathrm{As}$ 上生长 $2.2 \mathrm{ML}$ 的 InAs量子点最后覆盖6 $\mathrm{nm} \operatorname{In}_{0.15} \mathrm{Ga}_{0.85} \mathrm{As}$ ，本征区厚度 也为 $630 \mathrm{~nm}$. 在生长 InAs dots-in-well结构时, 生长 完InAs 量子点后中断 $30 \mathrm{~s}$, 促进In原子的迁移. 生长
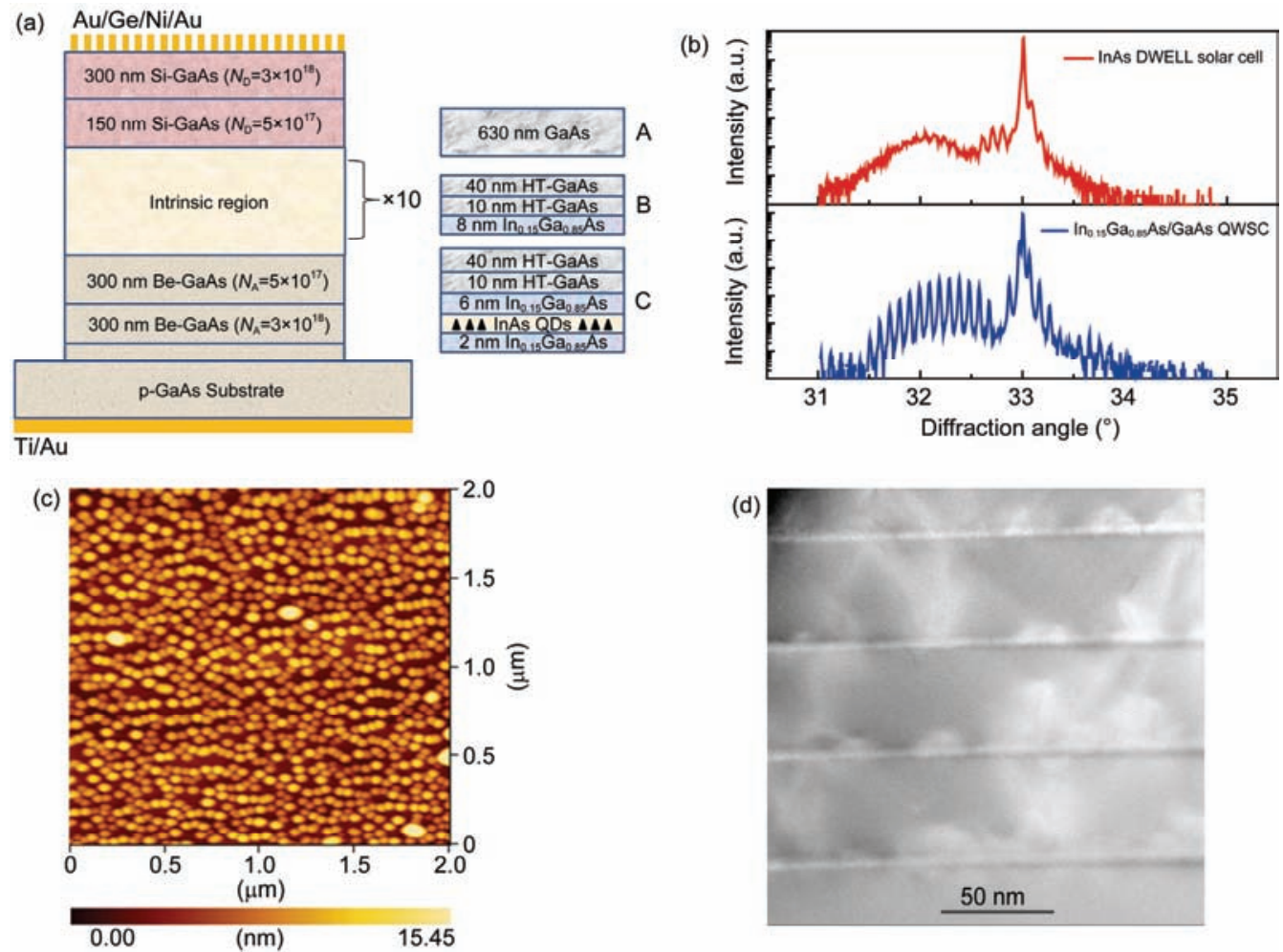

图 1 (网络版彩色)样品的结构和材料形貌表征图. (a) 器件结构: 标准GaAs太阳能电池(样品A), InGaAs/GaAs量子阱太阳能电池(样品B), InAs dots-in-well量子点太阳能电池(样品C); (b) InAs dots-in-well 太阳能电池和InGaAs/GaAs量子阱太阳能电池的X射线衍射图谱(004); (c) InAs 量 子点的原子力显微镜图(AFM); (d) InAs dots-in-well 太阳能电池的扫描隧道显微镜图

Figure 1 (Color online) The structure of the sample and the characterization of the material. (a) Device architecture: standard GaAs solar cell (sample A), InGaAs/GaAs quantum well solar cell (sample B) and InAs/InGaAs quantum dots solar cell (sample C); (b) X-ray diffraction (w/2o) spectra taken around the (004) reflection of InAs dots-in-well solar cell and InGaAs/GaAs quantum well solar cell; (c) atomic force microscope (AFM) image of the InAs quantum dots; (d) scanning transmission-electron microscopy (STEM) image of the InAs/InGaAs quantum dots solar cell 
时 $\mathrm{As}_{4}$ 压保持在 $1 \times 10^{-5}$ Torr $(1$ Torr $\approx 133.322 \mathrm{~Pa})$, $\mathrm{GaAs}$ 生长时衬底温度保持在 $580^{\circ} \mathrm{C}$, 生长含 $\mathrm{In}$ 组分的 区域时候衬底温度保持在 $500^{\circ} \mathrm{C}$. 在样品 $\mathrm{B}$ 和样品 $\mathrm{C}$ 中生长耗尽区的 $\mathrm{GaAs}$ 势垒时, 前 $10 \mathrm{~nm}$ 低温生长 $\left(500^{\circ} \mathrm{C}\right)$, 后 $40 \mathrm{~nm}$ 高温生长 $\left(580^{\circ} \mathrm{C}\right)$.

外延生长完成之后, 利用常规光刻剥离流程制 备出上电极图形, 通过电子束蒸发的方法, 蒸镀 $\mathrm{Ni} /$ $\mathrm{Au} / \mathrm{Ge} / \mathrm{Ni} / \mathrm{Au}(15 / 101 / 26 / 26 / 100 \mathrm{~nm})$ 到上电极和 $\mathrm{Ti} / \mathrm{Au}$ $(20 / 100 \mathrm{~nm})$ 到下电极. 电池器件大小是 $0.5 \mathrm{~cm} \times 0.5 \mathrm{~cm}$. 上电极占据单个器件面积的 $6 \%$. 未制作增反膜.

利用X射线衍射来观察外延片的晶体质量, 样品 $\mathrm{B}$ 和样品 $\mathrm{C}$ 的 XRD衍射如图 1(b)所示. 利用原子力显 微镜(AFM) 观察量子点表面形貌, 如图1(c)所示. 扫 描投射显微镜观察InAs 量子点dots-in-well结构, 如 图1(d)所示.

光电流响应谱(PC)是由卓立汉光DSR 100 系统测 得, 光致发光谱由自行搭建设备测量. 太阳能电池的 光伏特性由 Keithley 4200测试得出.

\section{2 实验结果与讨论}

通过改变低维纳米材料的组分和大小可以裁剪 材料的带隙, 从而调整器件的光电特性. 图1(b)显示 了样品 InGaAs/GaAs 量子阱太阳能电池 (样品 B) 和 InAs dots-in-well量子点太阳能电池 (样品 C) 的 XRD 图, 从图中可以看出样品 $\mathrm{B}$ 的衍射卫星峰清晰, 强度 高, 多周期样品结构完整, 界面清晰. 说明晶体质量 较高, 缺陷少; 样品 $\mathrm{C}$ 的衍射峰模糊数量少, 强度低, 说明插人 InAs 量子点后界面粗䊁度有所提高. 从图 1(c)量子点的AFM图中可以看出量子点密度为 $2 \times 10^{10}$ $\mathrm{cm}^{-2}$. 从图 1(d) 中量子点的 STEM图中也可以看出金 字塔型量子点高度约为 $12 \mathrm{~nm}$, 底边长 $27 \mathrm{~nm}$.

图 2 是样品 $\mathrm{C}$ 在 $50 \mathrm{~K}$ 时, 在激发功率 $20 \mathrm{~mW}$ 的 532 $\mathrm{nm}$ 激光照射下的光致发光谱(PL). 从图中看出量子 点呈现非对称的双模分布, 大的量子点的峰位在 $1243 \mathrm{~nm}$, 小的量子点的峰位在 $1195 \mathrm{~nm}$. GaAs衬底 峰在 $850 \mathrm{~nm}$.

图3 上部分是 3 个样品的光电流响应谱 $(\mathrm{PC})$, 下 部分是InGaAs 量子阱太阳能电池和InAs dots-in-well 量子点太阳能电池在 $220 \mathrm{~K}$ 时的PL谱当人射光波长 从 $500 \mathrm{~nm}$ 变化到 $1400 \mathrm{~nm}$ 时, 标准 $\mathrm{GaAs}$ 太阳能电池的 光响应从 $600 \mathrm{~nm}$ 开始上升, $860 \mathrm{~nm}$ 光电流达到最大, 然后迅速降低, 超过900 nm几乎没有响应. InGaAs量

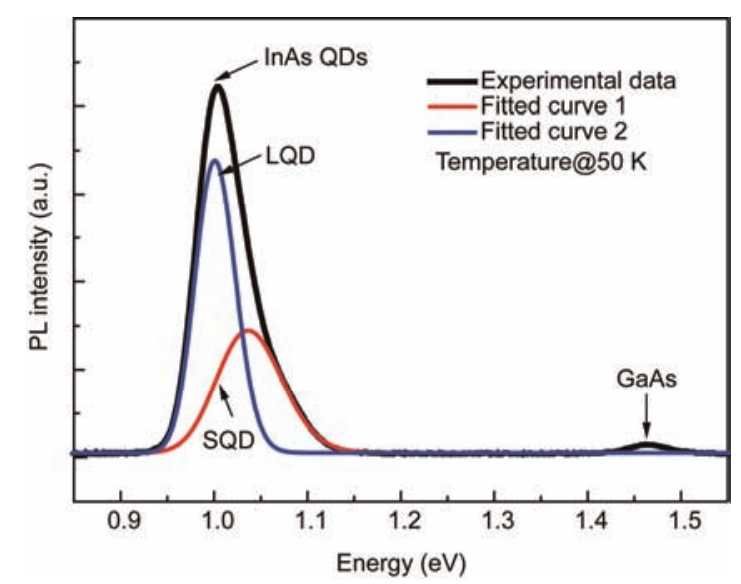

图 2 (网络版彩色) InAs dots-in-well 结构在 $50 \mathrm{~K}$ 时的光致发光谱

Figure 2 (Color online) Photoluminescence (PL) results for the 10-layers of InAs/InGaAs QDs solar cell (sample C) at the temperature of $50 \mathrm{~K}$

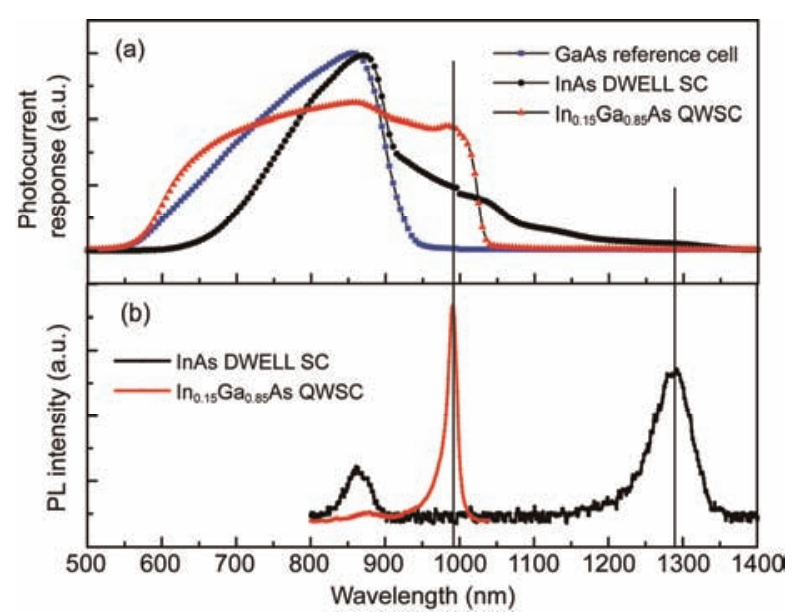

图 3 (网络版彩色) 3 种结构的太阳能电池的光电特性. (a) GaAs标准 电池、InGaAs 量子阱电池、InAs dots-in-well量子点电池的光电流响应 谱; (b) $220 \mathrm{~K}$ 下InGaAs量子阱和InAs dots-in-well结构的光致发光谱

Figure 3 (Color online) The optical-electrical characteristic of the three types of solar cells. (a) Photocurrent response of GaAs reference solar cell (sample A), InGaAs quantum well solar cell (sample B) and InAs dots-in-well solar cell (sample C); (b) the PL of quantum well solar cell (sample B) at room temperature and InAs dots-in-well solar cell (sample C) at $220 \mathrm{~K}$

子阱太阳能电池的光响应从 $600 \mathrm{~nm}$ 开始上升, 到达 $990 \mathrm{~nm}$ 后迅速下降, 对应于其在 $220 \mathrm{~K}$ 时的苂光峰. InAs dots-in-well量子点太阳能电池的光响应从 $650 \mathrm{~nm}$ 开始上升, 到 $880 \mathrm{~nm}$ 达到最大, 然后开始缓慢下降, 一直到 $1300 \mathrm{~nm}$ 以后光电响应才截止. 从图3中样品 的PC谱可以看出, 随着低维半导体材料, 量子阱量 子点的加人可以有效地调节光谱吸收波长. InAs dots-in-well结构量子点吸收波长可以扩展到 1300 $\mathrm{nm}$, 对应于 $1.0 \mathrm{eV}$ 带隙. 因此本文中调制得到的InAs 
dots-in-well结构的太阳能电池在多节太阳能电池的 设计中有广阔的应用前景.

图 4 是 GaAs 标准电池、InGaAs 量子阱、InAs dots-in-well量子点电池的 $J-V$ 特性曲线. 表 1 是上述 3 种电池的 $J-V$ 特性表. 由 $J-V$ 特性曲线看出, 在短路电 流方面, InGaAs量子阱电池比 GaAs标准p-i-n太阳能 电池高 $0.784 \mathrm{~mA}$, 增加了 7.9\%. InAs dots-in-well量子 点电池比 InGaAs 量子阱电池高 $2.97 \mathrm{~mA}$, 比 GaAs标 准p-i-n太阳能电池高 $3.754 \mathrm{~mA}$, 增加了 $37.8 \%$. 量子 点的加人, 降低了电池的带隙, 增加了近红外波段的 光吸收, 短路电流增加. 在开路电压方面, InGaAs量 子阱电池比 GaAs标准 $\mathrm{p}-\mathrm{i}-\mathrm{n}$ 太阳能电池低 $102 \mathrm{mV}$, InAs dots-in-well量子点电池比GaAs标准p-i-n太阳能 电池低 $651 \mathrm{mV}$. 量子阱和量子点的加人, 使得电池 的带隙降低, 降低了开路电压. 并且在InAs dotsin-well太阳能电池中, 量子点的加人引人了大量的 位错缺陷, 使晶体质量变差, 复合中心增多, 开路电 压降低, 光电转换效率降低.

对于III-V族化合物电池, 单片多结电池通常是 在底电池上直接外延生长下一个子电池, 中间通过 隧穿结连接, 电池的开路电压是各个子电池开路电 压之和, 而短路电流却等于子电池最小的短路电流. 因此, 尽管基于低维半导体材料的太阳能电池的效 率退化机制和抑制方式仍有待进一步研究, 但通过 设计加人量子阱和量子点等低维半导体材料, 增大 了短路电流, 缓解多结电池的电流阻塞效应. 因此, 在GaAs p-i-n子电池中引人低维纳米结构在少量增加 传统三结太阳能电池的开路电压基础上, 显著提高 电池的短路电流, 从而提升系统效率.

\section{3 结论}

本文设计了 $\mathrm{In}_{0.15} \mathrm{Ga}_{0.85} \mathrm{As}$ 量子阱、InAs dots-inwell量子点太阳能电池. 高分辨X射线衍射观察到了 多量子阱中的多级卫星峰, 表明量子阱界面陡峭. 通 过原子力显微镜和扫描透射显微镜观察到了量子点 的形貌和高度, 量子点的插人引进了大量的位错缺

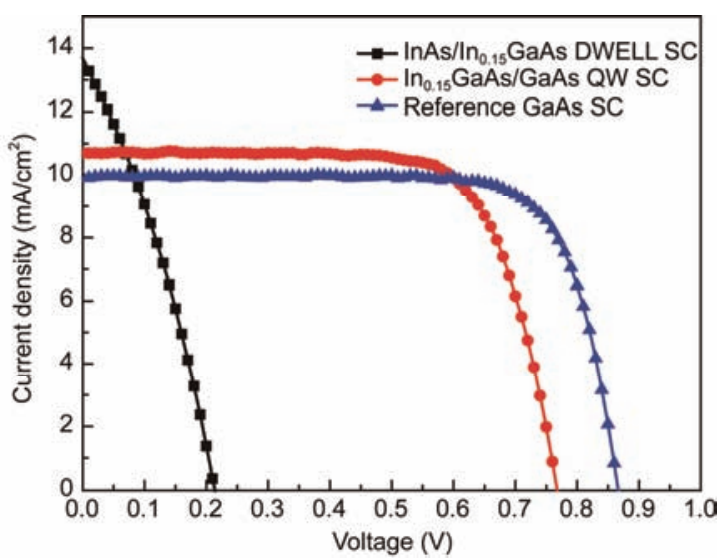

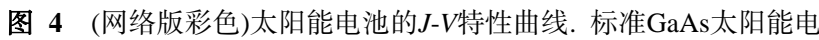
池、InGaAs量子阱太阳能、InAs dots-in-well量子点太阳能电池

Figure 4 (Color online) $J-V$ Characteristics for the InGaAs quantum well solar cell, InAs dots-in-well solar cell and GaAs reference p-i-n solar cell under 1.5 AM illumination

表 1 太阳能电池大的 $J-V$ 特性

Table 1 Device parameters for three solar cells in study

\begin{tabular}{ccccc}
\hline Sample & $V_{\text {oc }}(\mathrm{mV})$ & $J_{\text {sc }}\left(\mathrm{mA} / \mathrm{cm}^{2}\right)$ & Fill factor $(\%)$ & $\eta(\%)$ \\
\hline A & 215 & 13.68 & 32.7 & 0.94 \\
B & 768 & 10.71 & 72.3 & 5.95 \\
C & 866 & 9.926 & 76.4 & 6.57 \\
\hline
\end{tabular}

陷, 导致复合中心增多, 降低晶体质量, 引起室温光 致发光淬灭. 低温光致发光谱显示量子点在 $\mathrm{As}_{4}$ 束流 下呈现双模分布. 3 种电池的光电流响应谱显示量子 阱和量子点的插人可以调整带隙，有效增加近红外 波段的光吸收，其中InAs dots-in-well量子点太阳能 电池可以调整带隙到约 $1.0 \mathrm{eV}$, 吸收波长到 $1300 \mathrm{~nm}$, 电池的 $J-V$ 特性曲线显示InAs dots-in-well量子点太阳 能电池短路电流相比于 GaAs标准 $\mathrm{p}-\mathrm{i}-\mathrm{n}$ 电池增加了 $37.8 \%$. 相比于具有 $1.0 \mathrm{eV}$ 带隙的 $\mathrm{In}_{0.3} \mathrm{Ga}_{0.7} \mathrm{As}$ 和 GaInNAs, InAs dots-in-well量子点结构更易生长. 这 表明该InAs dots-in-well量子点太阳能电池有望改善 多结太阳能电池的设计中的电流阻塞效应, 在多结 太阳能电池的设计中具有广阔的应用前景.

\section{参考文献}

1 Dimroth F, Grave M, Beutel P, et al. Wafer bonded four-junction GaInP/GaAs//GaInAsP/GaInAs concentrator solar cells with $44.7 \%$ efficiency. Prog Photovolt Res Appl, 2014, 22: 277-282

2 Fujii H, Toprasertpong K, Wang Y, et al. 100-period, 1.23-eV bandgap InGaAs/GaAsP quantum wells for high-efficiency GaAs solar 
cells: Toward current-matched Ge-based tandem cells. Prog Photovoltaics Res Appl, 2014, 22: 784-795

3 Zhang Y, Wang Q, Zhang X B, et al. GaInP/GaInAs/GaInNAs/Ge four-junction solar cell grown by metal organic chemical vapor deposition with high efficiency. Chin Phys Lett, 2016, 33: 108801

4 Bauhuis G J, Mulder P, Haverkamp E J, et al. 26.1\% thin-film GaAs solar cell using epitaxial lift-off. Sol Energ Mater Sol C, 2009, 93: 1488-1491

5 Nakayama K, Tanabe K, Atwater H A. Plasmonic nanoparticle enhanced light absorption in GaAs solar cells. Appl Phys Lett, 2008, 93: 121904

6 Cotal H, Fetzer C, Boisvert J, et al. III-V multijunction solar cells for concentrating photovoltaics. Energ Environ Sci, 2009, 2: 174-192

7 Sato S I, Ohshima T, Imaizumi M. Modeling of degradation behavior of InGaP/GaAs/Ge triple-junction space solar cell exposed to charged particles. J Appl Phys, 2009, 105: 044504

8 Hubbard S M, Bailey C, Polly S, et al. Nanostructured photovoltaic for space power. J Nanophoton, 2009, 3: 031880

9 Barnham K W J, Ballard I, Connolly J P, et al. Quantum well solar cells. Phys E, 2002, 14: 27-36

10 Wang H X, Zheng X H, Gan X Y, et al. Designing of $1 \mathrm{eV} \mathrm{GaNAs/GaInAs} \mathrm{superlattice} \mathrm{subcell} \mathrm{in} \mathrm{current-matched} \mathrm{four-junction} \mathrm{solar}$ cell. J Semicond, 2016, 37: 014011

11 Kurtz S R, Allerman A A, Jones E D, et al. InGaAsN solar cells with $1.0 \mathrm{eV}$ band gap, lattice matched to GaAs. Appl Phys Lett, 1999, 74: 729-731

12 Geisz J F, Kurtz S, Wanlass M W, et al. High-efficiency GaInP/GaAs/InGaAs triple-junction solar cells grown inverted with a metamorphic bottom junction. Appl Phys Lett, 2007, 91: 023502

13 Volza K, Lacknera D, Németha I, et al. Optimization of annealing conditions of (GaIn)(NAs) for solar cell applications. J Cryst Growth, 2008, 310: 2222-2228

14 Yamaguchi M, Nishimura K I, Sasaki T, et al. Novel materials for high-efficiency III-V multi-junction solar cells. Sol Energy, 2008, 82: 173-180

15 Friedman D J. Progress and challenges for next-generation high-efficiency multijunction solar cells. Curr Opin Solid ST M, 2010, 14: 131-138

16 Mazzer M, Ballard I M, Bessiere A, et al. Progress in quantum well solar cells. Thin Solid Films, 2006, 511-512: 76-83

17 Walker A W, Theriault $\mathrm{O}$, Wheeldon J F, et al. Temperature dependent external quantum efficiency simulations and experimental measurement of lattice matched quantum dot enhanced multi-junction solar cells. IEEE J Photovolt, 2013, 3: 1118-1124

18 Sayari A, Ezzidini M, Azeza B, et al. Improvement of performance of GaAs solar cells by inserting self-organized InAs/InGaAs quantum dot superlattices. Sol Energ Mat Sol C, 2013, 113: 1-6

19 Dimroth F, Kurtz S. High-efficiency multijunction solar cells. MRS Bull, 2007, 32: 230-235

20 Hubbard S M, Bailey C G, Aguinaldo R, et al. Characterization of quantum dot enhanced solar cells for concentrator photovoltaics. In: Proceedings of Photovoltaic Specialists Conference (PVSC). Now York: IEEE, 2009

21 Ekins-Daukes N J, Lee K H, Hirst L, et al. Controlling radiative loss in quantum well solar cells. J Phys D: Appl Phys, 2013, 46: 264007

22 Guffarth F, Heitz R, Geller M, et al. Radiation hardness of InGaAs/GaAs quantum dots. Appl Phys Lett, 2003, 82: 1941-1943

23 Ngo C Y, Yoon S F, Tong C Z, et al. An investigation of growth temperature on the surface morphology and optical properties of $1.3 \mu \mathrm{m}$ InAs/InGaAs/GaAs quantum dot structures. Nanotechnology, 2007, 18: 365708

24 Wu J, Chen S M, Seeds A, et al. Quantum dot optoelectronic devices: Lasers, photodetectors and solar cells. J Phys D: Appl Phys, 2015, 48: 363001 


\title{
1.0 eV GaAs based InAs quantum dot solar cells
}

\author{
WANG WenQi ${ }^{1,2}$, WANG Lu ${ }^{1,2^{*}}$, JIANG Yang $^{1,2}$, MA ZiGuang ${ }^{1,2}$, SUN Ling $^{1,2}$, LIU Jie $^{1,2}$, \\ WANG WenXin ${ }^{1,2}$, JIA HaiQiang ${ }^{1,2}$ \& CHEN Hong ${ }^{1,2}$ \\ ${ }^{1}$ Beijing National Laboratory for Condensed Matter Physics, Institute of Physics, Chinese Academy of Sciences, Beijing 100190, China; \\ ${ }^{2}$ University of Chinese Academy of Sciences, Beijing 100049, China \\ * Corresponding author, E-mail: lwang@iphy.ac.cn
}

There are great improvements in III-V semiconductor solar cells including GaAs single junction solar cell and tandem solar cells in last decades. The common commercially used triple-junction solar cell mostly utilize a Ge bottom cell with an (In)GaAs and InGaP middle and top cell respectively. The (In)GaAs middle cell absorbs limited solar spectrum and show minimum short-circuit current in multiple junction solar cell, which determine the overall current of the cell. Theoretically, higher energy conversion efficiency will be obtained when introducea subcell with $1.0 \mathrm{eV}$ band gap in series to the $\mathrm{InGaP} / \mathrm{GaAs} / \mathrm{Ge}$ tandem structures. Lattice-matched GaInNAs and lattice-mismatched $\operatorname{In}_{0.3} \mathrm{Ga}_{0.7} \mathrm{As}_{\text {are }}$ two common choices for achieving $1.0 \mathrm{eV}$ band gap. However, the addition of $\mathrm{N}$ to GaAs has detrimental effects on the material quality, limiting its utility to approaches that required photocurrent. And the lattice mismatch makes thick $\mathrm{In}_{0.3} \mathrm{Ga}_{0.7}$ As heterogeneous epitaxial difficult. The incorporation of low band gap nanoscale materials, such as quantum well and quantum dots, into current limiting junction of a multijunction solar cell can tuning the effective bandgap and enhance the low-energy photon absorption, thereby increasing the short-circuit current.

The samples are grown by solid-source molecular beam epitaxy (V80H) on p-GaAs (001) substrates using an $\mathrm{As}_{4}$ source. Sample A is a standard GaAs solar cell with PIN structure. Sample B contains 10 period $8 \mathrm{~nm} \mathrm{In}_{0.15} \mathrm{Ga}_{0.85} \mathrm{As}$ QW and sample $\mathrm{C}$ contains 10 period InAs dots-in-well structure. The intrinsic region of these samples was at the same length of $630 \mathrm{~nm}$ to obtain the same build-in electric field. Besides the instinct region, the three samples are designed the same. The ohmic contact layer's doping concentration is $N_{\mathrm{D}} / N_{\mathrm{A}}=3 \times 10^{18} \mathrm{~cm}^{-3}$ and its thickness is $300 \mathrm{~nm}$. The emitter doping concentration is $N_{\mathrm{D}}=5 \times 10^{17} \mathrm{~cm}^{-3}$ and its thickness is $150 \mathrm{~nm}$; The base doping concentration is $N_{\mathrm{A}}=5 \times 10^{17} \mathrm{~cm}^{-3}$ and its thickness is $300 \mathrm{~nm}$. The As $s_{4}$ pressure and the InAs QDs growth rate are $1 \times 10^{-5}$ Torr and $0.1 \mathrm{ML} / \mathrm{s}$, respectively.

The XRD pattern of sample B (QWSC) shows clearly defined and intense satellite peaks indicating steep interface and periodicity quantum well. However, the XRD pattern of sample C (the InAs dots in well solar cell) shows blurring diffraction peaks which means increased interface roughness. Uniform QD structure with density of $2 \times 10^{10} \mathrm{~cm}^{-2}$ can be observed in SEM. From the STEM, we can see well-defined unrelated pyramidal quantum dots separated by a nominal $50 \mathrm{~nm}$ GaAs spacing. From the contrast, the pyramid InAs QDs are estimated to have the lateral dimension of $27 \mathrm{~nm}$ and the height of $12 \mathrm{~nm}$. The PC response of sample A rise at $600 \mathrm{~nm}$ and fall off at $870 \mathrm{~nm}$, which is corresponding to the GaAs bandgap according to the PL peak position; the PC response of QWSC (sample B) rise at $600 \mathrm{~nm}$ and fall off at $990 \mathrm{~nm}$, which is corresponding to the $\mathrm{In}_{0.15} \mathrm{Ga}_{0.85} \mathrm{As}$ bandgap in PL spectrum. The incorporation of $\operatorname{In}_{0.15} \mathrm{Ga}_{0.85} \mathrm{As}$ quantum wells in GaAs standard solar extend the absorption of solar spectrum from $900 \mathrm{~nm}$ to $1000 \mathrm{~nm}$. The wavelength region from $700 \mathrm{~nm}$ to $900 \mathrm{~nm}$ in PC of QWSC is weaker than the GaAs standard solar cell. The insertion of InAs QDs into QWSC can extend the infrared photon absorption to the wavelength of $1300 \mathrm{~nm}$. The insertion of InAs quantum dots into $\mathrm{In}_{0.15} \mathrm{Ga}_{0.85} \mathrm{As} / \mathrm{GaAs}$ quantum well solar cell extend the absorption of infrared light and the $J_{\mathrm{sc}}$ reaches $13.68 \mathrm{~mA} / \mathrm{cm}^{2}$, giving a $37.8 \%$ increase in short-circuit current over the baseline solar cell current. Because the voltage of multiple junction solar cell is the sum of the sub cell's voltage. The voltage decreasement with the insertion of InAs quantum dots do not influence the overall voltage of multiple junction solar cell.

In summary, the incorporation of quantum well and quantum dots in GaAs solar cell result in extended solar spectrum absorption and contribute to the sub-band gap current gains for GaAs solar cell. Especially, InAs dots-in-well solar cell can extend the absorption spectrum to the wavelength of $1300 \mathrm{~nm}$, and increase by $37.8 \%$ in short-circuit current, which shows great potential in mitigating current mismatch of multiple junction solar cell. Furthermore, designing new multiple junction solar cell becomes possible.

\section{quantum dots, III-V semiconductor, solar cells}

doi: 10.1360/N972017-00295 